Abstracta Iranica Abstracta Iranica

Revue bibliographique pour le domaine irano-aryen

Volume 22 | 2001

Comptes rendus des publications de 1999

\title{
Dīwān al-Hallāj. Éd. et présenté par 'Abduh Wāzin, Beyrouth, Dār al-jadīd, 1998, 319 p.
}

\section{Pierre Lory}

\section{(2) OpenEdition \\ 1 Journals}

Édition électronique

URL : http://journals.openedition.org/abstractairanica/36830

DOI : 10.4000/abstractairanica.36830

ISSN : 1961-960X

\section{Éditeur :}

CNRS (UMR 7528 Mondes iraniens et indiens), Éditions de l'IFRI

\section{Édition imprimée}

Date de publication : 15 mai 2001

ISSN : 0240-8910

\section{Référence électronique}

Pierre Lory, «Dīwān al-Ḥallāj. Éd. et présenté par 'Abduh Wāzin, Beyrouth, Dār al-jadīd, 1998, 319 p. », Abstracta Iranica [En ligne], Volume 22 | 2001, document 370, mis en ligne le 17 février 2010, consulté le 13 octobre 2020. URL : http://journals.openedition.org/abstractairanica/36830 ; DOI : https:// doi.org/10.4000/abstractairanica.36830

Ce document a été généré automatiquement le 13 octobre 2020.

Tous droits réservés 


\section{Dīwān al-Hallāj. Éd. et présenté par 'Abduh Wāzin, Beyrouth, Dār al- jadīd, 1998, 319 p.}

Pierre Lory

Mentionnons pour mémoire cette nouvelle édition du Dīwān ; 'A. Wāzin n'y apporte pas d'éléments nouveaux, il s'est simplement appliqué à reprendre en tâchant de les harmoniser au mieux les deux éditions de Massignon et d'al-šỉbī. La présentation et les notes sont claires, agréables à lire. Une soixantaine de pages d'introduction situent la problématique hallājienne avec précision et pertinence.

INDEX

Thèmes : 8 . Soufisme

\section{AUTEURS}

PIERRE LORY

EPHE - Paris 